\title{
Pathogenesis of endometrial gestational angiosclerosis in mares - An electron microscopic investigation
}

\author{
Susanne Reinstorf, Doris Schoon und Heinz-Adolf Schoon \\ Institut für Veterinär-Pathologie, Universität Leipzig
}

\begin{abstract}
Summary
To investigate the pathogenesis of endometrial gestational angiosclerosis endometrial biopsy samples of 13 broodmares of different ages and reproductive status were taken before breeding and after foaling and were examined by light and transmission electron microscopy. Independent of the quality and quantity of pre-gravid vascular lesions, three days post partum the blood vessels show identical findings in the intima and media: hypertrophy of cells, particularly myocytes, and a nearly complete disintegration of elastic fibres. During postpartum involution arteries and veins show an accumulation of elastic fibres in the adventitia, in the arterial vessels elastic fibres are present also in the membrana elastica interna. The frequency and severity of degenerative changes increase with parity of mares. Ageing processes, genetic influences, and short foaling intervals have to be considered as additional factors in the pathogenesis.
\end{abstract}

Keywords: mare, endometial vessels, gestational angiosclerosis, elastic fibres

\section{Elektronenmikroskopische Untersuchungen zur Pathogenese der endometrialen vaskulären Graviditätssklerose der Stute}

Licht- und elektronenmikroskopische Untersuchungen anhand von Endometriumbiopsien von 13 Zuchtstuten unterschiedlichen Alters (721 Jahre alt) und Reproduktionsstatus (0-15 Abfohlungen) dienten der Klärung der Pathogenese der endometrialen vaskulären Graviditätssklerose. Die Probenentnahme erfolgte vor der Belegung und 3,7,10 oder 28 Tage nach der Abfohlung. Unabhängig von der Qualität und Quantität prägravider vaskulärer Läsionen zeigen Intima und Media am dritten Tag posł partum identische Befunde: zelluläre Hypertrophie, besonders der Myozyten, sowie eine annähernd vollständige Desintegration der elastischen Fasern. Im Zuge der weiteren postpartalen Involution der Arterien und Venen akkumulieren die elastischen Fasern in der Adventitia sowie in der Membrana elastica interna der arteriellen Gefäße. Die Häufigkeit und der Schweregrad dieser degenerativen Veränderungen nehmen mit der Anzahl bisheriger Abfohlungen der Stute zu. Altersbedingte Prozesse, genetische Faktoren und kurze Zwischenfohlzeiten müssen als zusätzliche Faktoren bei der Entstehung der Angiosklerose der Stute in Betracht gezogen werden.

Schlüsselwörter: Pferd, Stute, Endometrium, Graviditätssklerose, elastische Fasern

\section{Introduction}

The gestational changes of the uterine vessels of various species have been described as "gestational sclerosis" in the beginning of the last century (Pankow 1906, Ahlborn 1920). Further investigations of endometrial blood vessels of the mare began in the 1990's (Schoon et al. 1994, Kriesten 1995, Grüninger et al. 1998, Schoon et al. 1999). During the 11 months of gestation of the mare, the endometrium accommodates analogously to the demands of highly increased vascular and glandular activity (Rossdale 1997). After foaling, the endometrium in general has a pre-gravid histological appearance by Day 14 post partum (Blanchard and Varner 1993, Steiger et al. 2002). The goal of this study was to describe the gestational changes of endometrial vessels of the mare and to specify the influence of pregnancy on the vessels. In order to obtain further information on the pathogenesis of endometrial angiosclerosis, the puerperal involution of the endometrial vessels was specifically considered.

\section{Material and Methods}

Endometrial biopsy samples from 13 Hanoverian brood mares differing in age (7-21 years old), in reproductive status and in parity (0-15 foals) were taken before breeding and
$3,7,10$ or 28 days after foaling (Tab. 1). Before breeding the mares had been barren for at least one year.

The biopsy samples were prepared for light microscopy using Haematoxylin-Eosin- and Picrosirius-Red staining (1\% SiriusRed-Solution: Bayer AG, Leverkusen, Germany) and for electron microscopy using Uranylacetate-Lead-and Tannic acidUranylacetate (Tannic Acid: Product Number T-8406, Sigma, Heidelberg, Germany; 4-Nitrophenol: Product Number 73560, Fluka, Neu Ulm, Germany) (Grüninger et al. 1998). The quality, degree, and distribution of degenerative lesions of endometrial vessels before breeding were determined and correlated to age and reproductive status of the mares. These results were compared with features after foaling. The processes of involution of the endometrial vessels were investigated additionally.

\section{Results}

Endometrial vascular findings before breeding

In the endometrial vessels of the maiden mare no vascular changes are detectable (Fig. 1). In young primipara the vessels are only mildly affected: arterial and venous vessels show 
Table 1 Age and reproductive status of mares, time of collection of post parturient endometrial biopsy samples

Alter und Reproduktionsstatus der Stuten, Zeitpunkt der Entnahme der Biopsie post partum

\begin{tabular}{ccc}
\hline $\begin{array}{c}\text { Age } \\
\text { (years) }\end{array}$ & $\begin{array}{c}\text { Number } \\
\text { of previous foalings }\end{array}$ & $\begin{array}{c}\text { Endometrial biopsy } \\
\text { after foaling } \\
\text { (in days post partum) }\end{array}$ \\
\hline 7 & 0 & 3 \\
7 & 1 & 3 \\
7 & 3 & 10 \\
10 & 4 & 3 \\
12 & 0 & 28 \\
12 & 5 & 28 \\
12 & 6 & 3 \\
14 & 1 & 3 \\
14 & 8 & 3 \\
15 & 5 & 3 \\
16 & 6 & 10 \\
16 & 10 & 7 \\
21 & 15 & 3 \\
\hline
\end{tabular}

a few crisp elastic fibres in the adventitia (mild perielastosis). Additionally single elastic fibres are present in the membrana elastica interna (MEI) of the arterial intima. By contrast the endometrial vessels of a 10-year-old mare with 3 to 4 foals are altered by a moderate panelastosis, especially affecting the arterial vessels. Mares up to 15 years old and which have had 5 to 6 foals exhibit severe angiopathies. Arterial vessels have more severe changes than veins and the severity of lesions intensifies with increasing size of vessels. 16-year-old mares with 6 foals or, in general, mares with more than 8

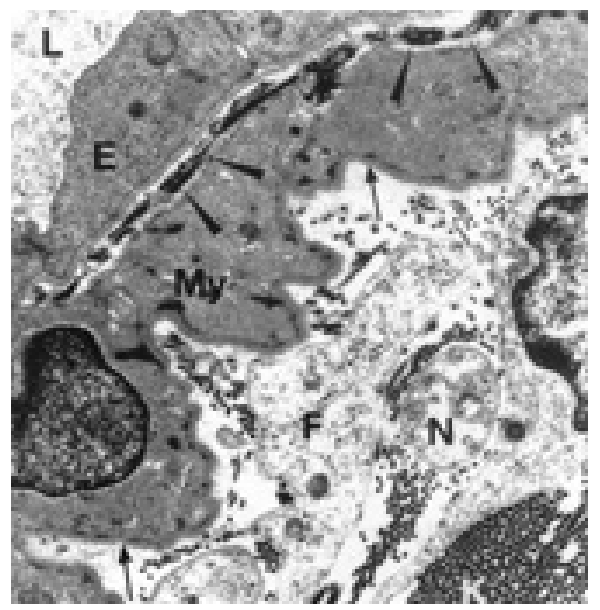

Fig. 1 Small normal artery of a 7-year-old maiden mare, showing a narrow subendothelial space and a clearly defined membrana elastica interna (arrowheads) within the intima, with a regular arrangement of contractile type smooth muscle cells (My) with narrow basallaminae (arrows) within the media. L, lumen. $\mathrm{E}$, endothelial cell. F, fibroblast. K, collagen fibres. N, nerve fibre. Tannic acid stain. TEM. x 7000 .

Normale kleine Arterie einer 7 Jahre alten Maidenstute: Schmaler subendothelialer Spalt und eine deutliche Membrana elastica interna (Pfeilspitzen) innerhalb der Intima. Media mit regulär angeordneten glatten Muskelzellen (My) und einer schmalen Basalmembran (Pfeile). L, Lumen. E, Endothelzelle. F, Fibroblast. K, Kollagenfasern. N, Nervenfaser. Tanninsäurekontrastierung TEM. x 7000. foals show severe to destroying alterations of their endometrial vessels: the walls of veins and arteries are strongly thikkened by many elastic and collagenous fibres. This is combined with a diminishment of the cellular elements and an obvious dysplasia of the media (Fig. 2).

\section{Changes of endometrial vessels shortly after foaling}

Three days post partum, the arterial and venous blood vessels show a hypertrophy of cells, particularly myocytes, combined with a nearly complete disintegration of the elastic fibres. Sub endothelial spaces are enlarged and contain mucopolysaccharides. Most myocytes near the intima are oriented longitudinally, with protrusions into the intima. Myocytes have increased in size and develop undulations in their shape. The cell membranes of adjacent myocytes "fit together" like the parts to a puzzle (Fig. 3). Small bundles of thin collagenous fibres occur in the intercellular spaces of the media and the myocytes are surrounded by collagenous fibres netlike. Independent of the quality and quantity of the pre-existing vascular lesions before foaling, the vessels of different mares exhibit identical findings affecting the intima and the media. The adventitia of endometrial blood vessels resembles that before breeding: dependent on the reproductive state of the mare

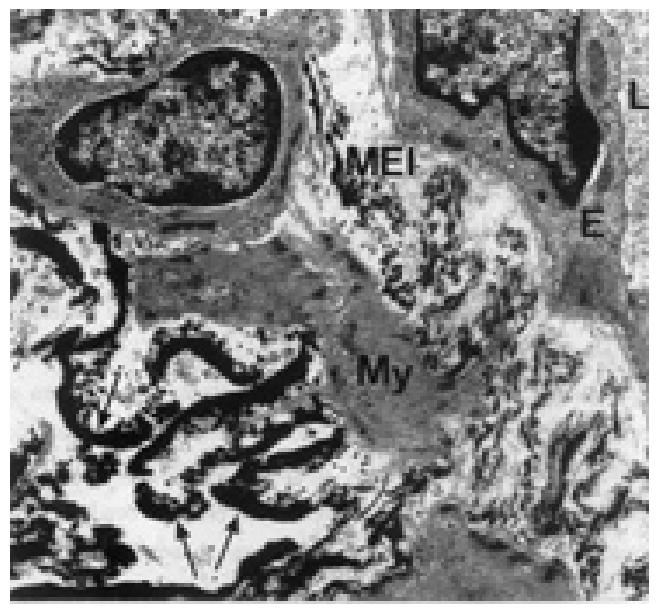

Fig. 2 Small artery of a 16 -year-old mare with 10 foals, showing a destroying panelastosis with a broad, irregular membrana elastica interna (MEI) within the intima, dysplasia, and atrophy of the media with deformed contractile type smooth muscle cells (My), many thick, mineralized, electron dense elastic fibres (arrows) within the adventitia. L, lumen. E, endothelial cell. Tannic acid stain. TEM. x 7000. Kleine Arterie einer 16 Jahre alten Stute nach 10 Abfohlungen. Destruierende Panelastose mit einer breiten, irregulären Membrana elastica interna (MEI) innerhalb der Intima. Die dysplastische und atrophische Media besteht aus deformierten glatten Muskelzellen (My). In der Adventitia viele dicke, mineralisiente, elektronendichte elastische Fasern (Pfeile).L, Lumen. E, Endothelzelle. Tanninsäurekontrastierung TEM. $\times 7000$.

there are various amounts of elastic and collagenous fibres (Fig. 4). The lymphatic vessels are not altered.

During the involution (Day 7 to 28 post partum) a remodelling of elastic fibres by cellular elements of the vascular wall is obvious. Arteries and veins show an accumulation of elastic fibres in the adventitia, in arterial vessels (including smallest arterioles); they are also present in the MEI. Ultra structural observations indicate that the cellular elements of the 
vascular wall, especially fibroblasts, are involved in the synthesis of elastic and collagenous fibres.

\section{Discussion}

Due to the demands of gestational stressing, the endometrial blood vessels are remodelled actively: intima and media of arterial and venous vessels show hypertrophy of the cells combined with a nearly complete disintegration of elastic fibres. This suggests active growth of the endometrial vessel wall (rather than an only passive dilation), comparable to uterine vessels in women (Schwarz and Hawker 1950). The media (together with myocytes) seems to be important for the adaptability of endometrial blood vessels during gravidity. Force-generating capacity and passive stiffness are supposed to be increased although connective tissue is decreased. This could be based on hypertrophy and hyperplasia of myocytes and increased smooth muscle content. Analogous changes of uterine arteries of near-term sheep are interpreted as pregnancy-induced hyperplasia and hypertrophy of myocytes, and alterations in the organization and orientation of the collagen matrices (Griendling et al. 1985). The present study indicates that the arrangement of hyperplastic myocytes and crisp collagenous fibres shortly after foaling is comparable with the

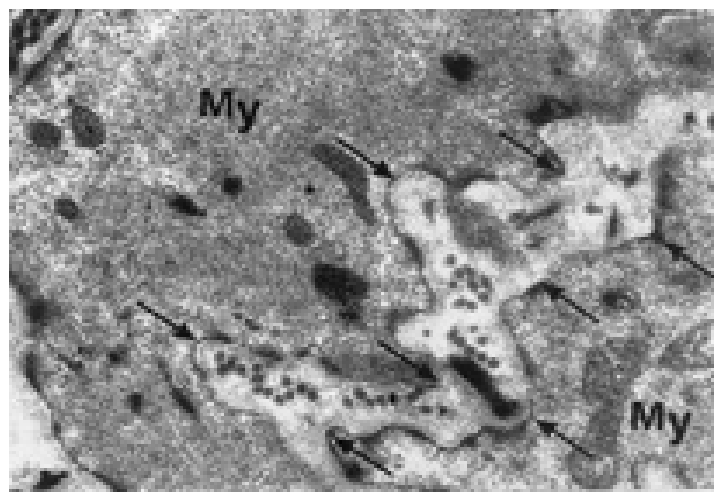

Fig. 3 Myocytes (My) of a small artery of the third day post partum, showing undulations in their shape (arrows) Tannic acid stain. TEM. x 12000 .

Myozyten (My) einer kleinen Arterie am dritten Tag post partum mit undulierender Kontur(Pfeile). Tanninsäurekontrastierung. TEM x 12000.

coherent structure of a wall, wherein the stones are represented by the myocytes and the cement is represented by the collagen. This explanation additionally supports increased stiffness of the vessel wall.

The gestational sclerosis of endometrial vessels could be considered a compensatory reaction on vascular stressing: after foaling the blood vessels are remodelled analogously to decreased functional vascular demands. Synthesis of elastic fibres causes a contraction of blood vessels as a physiologic process. The remodelling processes within the endometrial vascular walls during gravidity and puerperium are induced and controlled by hormones, haemodynamic changes, and growth factors (Grüninger et al. 1998).

The present study indicates a high stress capacity to endometrial vessels of the mare: vessels, even those which are markedly sclerotic after several gestations, seem to regenerate and become actively functional again, maybe with some physiological compromise. This is probably due to hormonal influences. Sclerotic uterine arteries of women show similar regenerative processes during yet another pregnancy (Gilman 1959). The amount of collagenous and elastic fibres and the frequency and severity of degenerative changes in endometrial vessels increase with the number of foalings (Grüninger et al. 1998). This leads to the conclusion that parity is the dominant factor in the pathogenesis of vascular endometrial alterations. Age related influences on the regenerative capacity of the endometrial vessels wall has to be expected in mares older than 16 years. This phenomenon is interpreted as indicative to the exhaustion of regeneration processes (Kriesten 1995, Schoon et al. 1999). By contrast, equine ovarian arteriosis is predominantly caused by age-related remodelling processes (Aupperle et al. 2003). Genetic influences have to be considered as additional factors in the pathogenesis. The fact that the amount of elastic fibres increases with the number of foalings could be explained by the persistence of elastic tissue in the vessel wall, especially in the adventitia, during gravidity of multiparous mares. In a similar manner, generally more marked arterial changes of multiparous women are explained (Maher 1959). A reduced elasticity and contractibility of fibroelastic vessels with atrophy of the media associated with a reduced endometrial perfusion could have

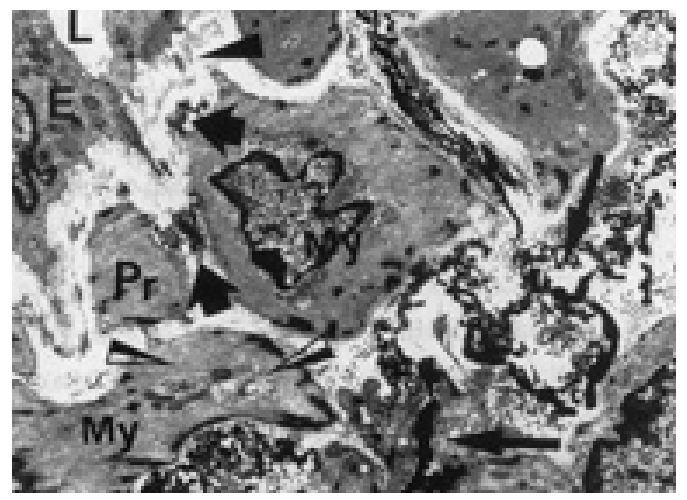

Fig. 4 Small artery of a 15-year-old mare with 9 foals on the third day post partum, showing an enlargement of the subendothelial space due to oedema and the deposition of mucopolysaccharides (arrowheads) and fragments of the membrana elastica interna (thick short arrows), which consist mainly immature elastic fibres and a constricted protrusion ( $\mathrm{Pr}$ ) of a myocyte within the intima; longitudinal oriented smooth muscle cells (My) with prominent organelles (half-marked arrowheads) within the media; thick, mineralized, electron dense elastic fibres within the adventitia (long arrows). L, lumen. E, endothelial cell. F, fibroblast. Tannic acid stain. TEM. x 4400. Kleine Arterie einer 15 Jahre alten Stute mit 9 Abfohlungen am 3. Tag post partum. Der subendotheliale Spalt ist verbreitert durch ein Ödem, Ablagerungen von Mukopolysacchariden (Pfeilspitzen) und Fragmenten der Membrana elastica interna (dicke kurze Pfeile), welche überwiegend unreife elastische Fasern aufweist. Abgeschnürte Protrusionen (Pr) der Myozyten in der Intima. Media mit longitudinal ausgerichteten glatten Muskelzellen (My) und prominenten Organellen (halbmarkierter Pfeil). In der Adventitia dicke, mineralisierte elektronendichte elastische Fasern (lange Pfeile) L, Lumen. E, Endothelzelle. F, Fibroblast. Tanninsäurekontrastierung TEM. x 4400.

direct negative influence on the nourishment and the development of the conceptus (Schoon et al. 1998). In mares with endometrial angiopathies a relatively high resistance of the uterine artery wall was measured by Doppler sonography (Blaich et al. 2001). 
The involution of the equine endometrial arterial vessels lasts until four weeks after foaling; veins regress earlier. If a mare is bred successfully during foal heat, the alterations of the endometrial vessel are probably more intense. In buffalo cows the process of vascular involution is often interrupted by a new pregnancy (El-Etreby 1969). Additionally the blood supply of incompletely involuted endometrial vessels could be insufficient for a new embryo. In that manner, it has been considered that the decreased pregnancy rate associated with foal heat breeding is caused by a failure of the incompletely involuted uterus (particularly the endometrium) to support a developing embryo (Roberts 1986). Therefore breeding during foal heat should be considered carefully with special regard to endometrial vascular involution. The process of involution, accompanying circumstances like retained placenta and the time of ovulation and the age of the mare should be considered in breeding during foal heat.

\section{Conclusions}

The frequency and severity of endometrial angiosclerosis is a parity related condition; ageing processes and short foaling intervals may play an additional role. Breeding in the foaling heat, especially in multiparous mares, should be considered carefully.

\section{References}

Ahlborn E. (1920) Über den histologischen Bau der Arteria uterina media des Rindes und deren Veränderungen während und nach der Gravidität (Histologic features of arteria uterina of the cow and changes during and after gravidity). Med. Vet. Diss. Hannover

Aupperle H., Hasenbein I., Ellenberger C., Ludwig S., Schoon D. und Schoon H.-A. (2003) Histopathological findings in ovarian vessels in comparison to the alterations in extraovarian, extrauterine and uterine vessels in the mare. Pferdeheilkunde 19, 589-594

Blaich U., Bartmann C. P., Schoon D., Klug E. und Schoon H.-A. (2001) Comparative Doppler sonographic and pathohistologic investigations in the uterine artery in the horse. Pferdeheilkunde 17,687

Blanchard T. L. und Varner D. D. (1993) Uterine involution and postpartum breeding. In: McKinnon A. O. und Voss J. L. (ed), Equine reproduction. 622

El-Etreby M. F. (1969) Morphologic studies on the peripheral circulation of the genital organs in buffaloes with special reference to spontaneous arteriosclerosis in animals. Zbl. Vet. Med.16, 865893

Gilman T. (1959) Reduplication, remodelling, regeneration, repair and degeneration of arterial elastic membranes. Arch. Path. 67, 634-642
Griendling K. K., Fuller E. O. und Cox R. H. (1985) Pregnancy-induced changes in sheep uterine and carotid arteries. Am. J. Physiol. 248, 658-665

Grüninger B. U., Schoon H.-A., Schoon D., Menger S. und Klug E. (1998) Incidence and morphology of endometrial angiopathies in mares in relationship to age and parity. J. Comp. Path. 119, 293309

Kriesten H. (1995) Zur prognostischen Bedeutung von Angiopathien im Rahmen der Kategorisierung von Endometriumbiopsien bei Stuten. (Prognostic value of endometrial vascular changes within the categoriziation system of endometrial biopsies of mares). Med. Vet. Diss. Hannover

Maher J. A. (1959) Morphologic and histochemical changes in postpartum uterine blood vessels. Arch. Pathol. 67, 175-180

Pankow R. (1906) Graviditäts-, Menstruations- und Ovulationssklerose der Uterus- und Ovarialgefäße (Gestational, menstrual and ovulatory sclerosis of uterine and ovarial blood vessels). Freiburg/Br., Germany. Arch. Gynaekol. 80, 271-282

Roberts S. J. (1986) Veterinary obstetrics and genital diseases. Theriogenology; 3rd ed. Woodstock, VT, published by the author

Rossdale P. D. (1997) The uterus, an organ of many roles. Pferdeheilkunde 13, 427-430

Schoon D., Schoon H.-A. und Klug E. (1994) Angiopathien im Endometrium der Stute: Diagnose und prognostische Bedeutung (Endometrial angiopathies in mares: diagnosis and prognostic value). Wiesbaden, Germany. Dtsch. Vet. Med. Gesellschaft (ed): 13. Fachtagung der Fachgruppe Pferdekrankheiten 17-29

Schoon H. -A., Kersten F., Schoon D. und Aupperle H. (1998) Equine placental development and postparturient uterine involution processes: Pathohistological, immunohistological and clinical findings. Havemeyer Foundation Workshop on Equine Placentitis, Lexington, Kentucky, USA, 15.-17.10.1998, Proceedings, R \& W Publications, Newmarket, 10-11

Schoon D., Schoon H.-A. und Klug E. (1999) Angioses in the equine endometrium - Pathogenesis and clinical correlations. Pferdeheilkunde 15, 541-546

Schwarz O. H. und Hawker W. D. (1950) Hyperplasia and hypertrophy of the uterine vessels during various stages of pregnancy. Am. J. Obst. Gynaecol. 60, 967-976

Steiger K., Kersten F., Aupperle H., Schoon D. und Schoon H.-A. (2002) Puerperal involution in the mare - morphological studies in correlation with the course of birth. Theriogenology 58, 783786

Prof. Dr. Heinz-Adolf Schoon

Institut für Veterinär-Pathologie

Universität Leipzig

An den Tierkliniken 33

04103 Leipzig

schoon@rz.uni-leipzig.de 